\title{
Effect of Employees Empowerment in Achieving Reality and Reducing Turnover in the Jordanian Industrial Companies
}

\author{
Dr. Bilal Khalaf Sakarneh \\ Head of business Department, Isra University, Jordan
}

Received: May 12, 2019 Accepted: May 29, 2019 Published: July 15, 2019

doi:10.5296/ber.v9i3.15098ＵRL: https://doi.org/10.5296/ber.v9i3.15098

\begin{abstract}
This research aimed at finding out effect of the empowerment in employee's reality and reducing turnover in the Jordanian industrial companies.

Study sample consisted of those who occupy the supervisory and administrative jobs in the industrial companies in Amman city, there number (250) individuals divided into categories. (250) questionnaire was distributed for the analysis. and (200) were retrieved by (80\%), and after testing the questionnaires for their validity for the statistical analysis (29) questionnaires were excluded for their invalidity for the statistical analysis process, so the total number of the valid questionnaires became (171) questionnaires. The study reached the follow:

The presence of a linear relationship between the empowerment variables (Training, providing the required information, delegating the authority, and participation), and the employees reality variables and reducing turnover (customers services, customers loyalty).

The researcher recommended a number of recommendations, the most important:

The work to disseminate the empowerment culture between the employees in the Jordanian industrial companies through enhancing the organizational values and traditions that motivate for achieving that goal.
\end{abstract}

Keywords: Empowerment, Employees Reality, Turnover, Jordanian industrial companies.

\section{Introduction}

Empowerment concept became the interest of researches from different domains to implant the responsibility spirit in the employees, and to show the effect of empowerment in improving the organizational performance and its effect in the organization through motivating them and engaging them in the decision making process, in addition to building 
trust between the management and the employees.

Employees performance and their presence at work without absentation is considered one of the topics that include the strategic dimension for the work to achieve the objectives of the organization through the distinguish performance so the outputs of the performance to be performance aspect and the reason for the organization survival, growth, and enhancing its competitive advantage.

There are many reasons for employee turnover, such as work conditions, weekly and annual vocation, job security and work-life- balance.

Wheelen and Hunger (2008) see performance as "The final result of the organization's activities", it represents an occupational behavior aims at accomplishing the works by the employees.

Referring to the empowerment, it means giving the employee, the freedom to act and achieving the participation in the decisions making, and through empowerment trust emerges and expanding the flow of information, increasing the opportunities for understanding and dialogue.

From this point this research comes to find out effect of empowerment in employees reality and reducing turnover in the Jordanian industrial companies

\section{Objectives of the Research}

- To find out the relationship between employees empowerment and employees reality and reducing turnover in the Jordanian industrial companies.

- To show effect of employees empowerment in employees reality and reducing turnover in the Jordanian industrial companies.

- To find out if there is an effect of the empowerment variables in the performance (customers service and customers loyalty).

- Determining if there is a linear relationship between empowerment variables (Training, giving the required information, delegation the authority and the participation) and employees realty and reducing turnover variables at significance level $(\mathrm{a} \leq 0.05)$.

\subsection{Importance of the Research}

Importance of the research stems from dealing with a problem that has not received the due interest by the researchers and the executives in the organizations, represents in investigating effect of empowerment in the employees reality and reducing turnover.

\subsection{Research Problem}

Empowerment is one of the tools that helps to develop the skills of employees in business organizations and increase their level of loyalty to these organizations, which contributes to building leadership and improving human resources and enhance their abilities 
Al-Rasheedi(2011).

Also, the previous studies that had addressed the empowerment topic did not show sufficiently the nature of the relationship between effect of employees empowerment in employees reality and reducing turnover.

Therefore, this study was used to measure the impact of empowerment in reducing the turnover of workers in business organizations, especially in industrial companies.

\subsection{Research Questions}

This research aims at answering the following questions:

- Is there a relationship between the employees empowerment and their reality and reducing turnover?

The researcher has built this model referring to studies conducted by:

- Glor, (2001)

- Heskett et al. (1994)

- Stirr, (2003)

- Al-Obaidi (2013)

- Sezer, (2009)

\subsection{Research Model}

- Dependent Variable Independent Variable Empowerment

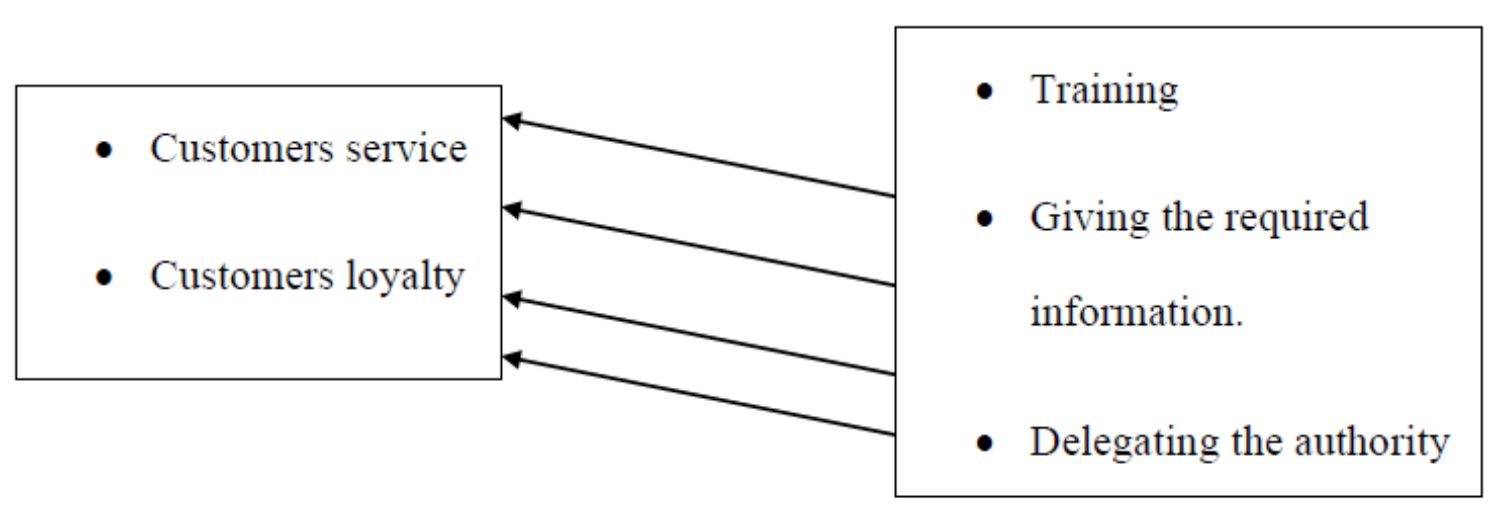

\subsection{Research's Terms}

Empowerment: It means giving the employees the authority in setting their goals and making the decisions and solving the problems in the range of their responsibilities and authorities (Lee, 2012).

Performance Reality and Reducing Turnover: The outputs the organization seek to achieve at the short and long terms (Morgan et al, 2009). 


\section{Macrothink}

Business and Economic Research

ISSN 2162-4860

2019, Vol. 9, No. 3

Customers Loyalty: Are the organization assets who provide the company with fixed income (Sorina, 2009).

Customers Service: It represents in the method and way in dealing with the customers (Al-Jareeri, 2006).

\section{Theoretical Frame and Previous Related Studies}

Empowerment can be defined as one of the means of the modern management, to encourage the individuals to hold the responsibility in the decision making, and achieving that through delegating the authority to lower administrative levels in the organization (Lee, 2012).

\subsection{Benefits of Employees Administrative Empowerment}

Through the empowerment literature. Two general trends for empowerment in the work environment were determined:

- The communicative trend through organizing the communication between the employees in the employees, and the motivational trend through providing the incentives to the employees.

It is believed that empowerment occurs when the top levels in the organizational structure engage the lower levels in the authority (Moke, 2012).

Administrative empowerment guarantees reality of the performance, and better utilizing the human resources, making the work more value and meaningful, and more motivating.

Al-Rasheedi (2011) suggested the following means to be used to empower the employees:

- The management trust in the employees abilities.

- Management high expectations and hopes about the employees capacities and level of their performance.

What is the effect of empowerment in employees reality and reducing turnover?

- Allowing the employees to contribute in the decision making process.

- Proving the employees the freedom and autonomy in selecting the way they see to execute their works.

\subsection{Basics of the Administrative Empowerment}

1. Employees Education: Every employee should be educated in the organization because education leads to increase the employees effectiveness which in turn leads to its success.

2. Motivation: The management should plan how to encourage the subordinates to accept the empowerment idea, and to show their vital role in the organization success through the awareness and the orientation programs. 
3. Respect:Respect is the core of the empowerment, it is the belief that every employee in the organization is able to contribute in it through developing and innovating his work.

\section{Steps For Employees Empowerment:}

First step : Need for Change

Second step : Determining the decisions in which the subordinates participate

Third step : Forming the team works

Fourth step : Providing the information. (Lee, 2012)

Fifth step : Selecting the relevant individuals

Sixth step : Providing the training (Al-Obaidi, 2013)

Since training is an elaborated way aims at equipping the individuals with the required skills in order to achieve the assigned to them tasks.

\subsection{Importance of Training}

Importance and benefits of training reside in three basic sides:

1. Increasing productivity and improving the organizational performance.

2. Training contributes to the creation of positive internal and external attitude toward the company.

3. Training is necessary for the companies at the administrative levels, because there is no way for development except through the interest in the training processes (Abbas \& Ali, 2011).

Organization might face obstacles in the empowerment application, including the follow:

1. Lack of the desire for the change.

2. Middle management for of loss of the jobs and the authority.

3. Employees fear of accountability.

4. Weak incentive system.

5. Preferring the traditional managerial leadership method. (Bataineh, 2008).

\subsection{Importance of Customer Loyalty}

Importance of the organizational loyalty for the individual emerges from feeling belonging to something important in his life, it represents in merging, love and trustworthy the individual shows towards something important to him.

Organizational loyalty is considered one of the prominent aspects in the organizations, because of its effect in the performance of the organizations and the employees, through 
placing the public interest infront of the personal interest (Al-hathlool, 2008).

Some of the factors helping in developing the customer loyalty include satisfying the employees' needs, their need for security and feeling the assurance in the organization, they seek to be appreciated and loved and belong to the group, and to achieve self-actualization, because the organization that does not help them to satisfy their needs will find no stability place for them (Al-Awad\& Al-Haran, 2009).

\section{Literature Review}

1. Al-Fallaq\& Ben Nafla (2011). Study entitle "Effect of the Administrative Empowerment in the Employees Creativity" case study of the Jordanian telecommunication Group.

The study aimed to find out the theoretical concepts relating to the managerial empowerment and managerial creativity, and level of the managerial empowerment.

The study reached that level of applying the managerial empowerment was medium, and the dimensions forming the prevailing managerial empowerment are: delegating the authority, training, effective communication \& employees motivation.

2.Al-Rasheedi (2011) study entitle "Effect of the Psychological Empowerment in achieving the competitive advantage: Field study on the Kuwaiti insurance companies".

This study aimed to find out the reality of the psychological empowerment in the Kuwaiti insurance companies, and to know its effect in achieving the competitive advantage, study population consisted of the Kuwaiti insurance companies, the number of the retrieved questionnaire was (114) questionnaires after analyzing the data, the study reached the following results:

The presence of effect of all psychological empowerment dimensions (influence, eligibility, work value and autonomy) in achieving competitive advantage, and the absence of differences with statistically significance at sig level $(a \leq 0.05)$ between means of the study individual answers towards the competitive advantage attribute to the employees' demographic and job variables.

3.Sanjar\& Levin (2012) study entitle "Using old stuff in New ways: Innovation as A case" aimed to find out the nature of excellence and the mechanism through which emerges the institutional creativity" the study reached the results that creativity emerges from the development in knowledge and the present experience, and using them in new ways to solve the production and marketing problems in the companies, and to satisfy the employees, social and psychological needs.

4.(Ogden, 2012) study entitle "Empowerment and Accountability: Evidence from the UK"This study aimed at giving a comprehensive perspective about effect of empowerment by disclosing the managers perception about what controls empowerment, and effect of empowerment in their experiences in accountability of their subordinates, the questionnaire were distributed to the manager and the use of the interviews in the UK.

The study reached that the manager practices vary according to their perception of the 
empowerment concept, and accountability plays more important role in the future in encouraging the employees to engage in the managerial empowerment process.

\section{Research Methodology}

This research is a descriptive analytical relational research method, which is considered relevant to provide accurate picture and adding facts and knowledge's which help in understanding what the research aims to achieve.

The researcher has referred to the related previous studies, references and different periodic which have addressed the topic of the present research in an attempt to enrich the research's theoretical frame.

The using the field survey on a sample of supervisors and administrators, with the use of the questionnaire which has been developed for the research's purposes.

\subsection{Study Population and Sample}

Study population consisted of those who occupy the supervisory and administrative jobs, their number (250) individuals in the Jordanian industrial companies, while the study sample was consisted of (250) individuals.

\subsection{Analysis Unit}

Analysis unit consisted of those who occupy the supervisory and administrative jobs (250) individuals divided into the following categories as seen in table 1.

Table 1.Study sample analysis unit from those who occupythe supervisory jobsand administrative jobs

\begin{tabular}{|l|l|}
\hline Supervisory jobs and administrative jobs & Number \\
\hline Manager & 32 \\
\hline Deputy of the manager & 29 \\
\hline Head of division & 50 \\
\hline Supervisor & 60 \\
\hline Total & $\mathbf{1 7 1}$ \\
\hline
\end{tabular}

(250) questionnaire were distributed, and (200) were retrieved by (80\%), and after testing the questionnaires for their validity for the statistical analysis (29) questionnaires were excluded for their invalidity for the statistical analysis process, so the total number of the valid questionnaires became (171) questionnaires by (85.5\%) from the total of the retrieved questionnaires.

\subsection{Research Instruments}

1. Secondary sources, by referring to the secondary data represent in the books, Arabic and foreign related sources.

2. Primary sources: To process the analytical sides, data was collected through the questionnaire which has been developed by the researcher as the main instrument for 
the research, using (Five- point- Likert Scale), and then using the statistical program (SPSS. Ver. 21).

\subsection{The Used Statistical Treatment}

- Frequencies and percentage.

- Means.

- Standards Deviations.

- Cronbach Alpha coefficient to measure stability of the questionnaire, and value of the internal consistency and degree of the answers validity to the questionnaire's items.

- Canonical Correlation Analysis.

- Multiple Regression Analysis.

\subsection{Research Results}

Table 2.Means and Standard Deviation for the Training Dimension

\begin{tabular}{|c|c|c|c|c|c|c|c|}
\hline No. & The item & Means & S.D & $\begin{array}{c}\mathrm{T} \\
\text { value }\end{array}$ & $\begin{array}{l}\text { Sig } \\
\text { level }\end{array}$ & $\begin{array}{l}\text { Level of the } \\
\text { importance }\end{array}$ & $\begin{array}{l}\text { Order of the } \\
\text { item } \\
\text { importance }\end{array}$ \\
\hline $1-$ & $\begin{array}{l}\text { The company's management adopts } \\
\text { a clear training plan based on the } \\
\text { training needs related to the work }\end{array}$ & 3.80 & 0.78 & 11.993 & 0.000 & High & 1 \\
\hline $2-$ & $\begin{array}{l}\text { The company's management } \\
\text { provides the needed training courses } \\
\text { to develop the employees skills }\end{array}$ & 3.75 & 0.84 & 11.75 & 0.000 & High & 2 \\
\hline $3-$ & $\begin{array}{l}\text { The company's management builds } \\
\text { training programs specific to raise } \\
\text { the employees efficacy }\end{array}$ & 3.70 & 0.92 & 9.881 & 0.000 & High & 3 \\
\hline $5-$ & $\begin{array}{l}\text { The company's management } \\
\text { depends in determining the training } \\
\text { needs on the results and the outputs } \\
\text { evaluation and performance } \\
\text { indicators }\end{array}$ & 3.49 & 0.95 & 5.530 & 0.000 & medium & 4 \\
\hline 4- & $\begin{array}{l}\text { The company provides the relevant } \\
\text { conditions to benefit from the } \\
\text { acquired skills and information from } \\
\text { the training }\end{array}$ & 3.42 & 0.98 & 6.697 & 0.000 & medium & 5 \\
\hline $6-$ & $\begin{array}{l}\text { The company's management aims to } \\
\text { providing the employees with } \\
\text { specific skills at work through } \\
\text { sending them in training courses } \\
\text { abroad }\end{array}$ & 3.35 & 1.11 & 4.073 & 0.000 & medium & 6 \\
\hline
\end{tabular}


\begin{tabular}{|l|l}
\hline $7-$ & The company's management recruits
\end{tabular} the qualified experts and trainers to train the employees

Mean and general standard deviation for the training dimension

\begin{tabular}{|l|l|l|l|l|l|}
\hline 3.20 & 1.16 & 3.312 & 0.022 & medium & 7 \\
\hline 3.53 & 0.86 & & & & \\
\hline
\end{tabular}

Table 2 clarifies a description of the answers of those who occupy the supervisory Jobs on the clauses related to the training dimension.

Their means ranged between (3.20-3.80), and the highest mean was for the clause (1), with mean (3.80) and standard deviation (0.87), and the lowest mean was for item (7) with mean (3.20) and standard deviation (1.16), the general mean for the dimension reached (3.53) on likert five point scale.

Table 3.Means and Standard Deviation for Delegating the Authority

\begin{tabular}{|c|l|c|c|c|c|c|c|}
\hline No. & \multicolumn{1}{|c|}{ The Item } & Means & S.D & $\begin{array}{c}\text { T } \\
\text { value }\end{array}$ & $\begin{array}{c}\text { Sig } \\
\text { level }\end{array}$ & Level & Rank \\
\hline $8-$ & $\begin{array}{l}\text { My direct boss authorizing me the sufficient } \\
\text { authority to perform my occupational tasks }\end{array}$ & 3.73 & 0.880 & 10.863 & 0.000 & High & 1 \\
\hline $9-$ & $\begin{array}{l}\text { My direct boss grants me the sufficient flexibility } \\
\text { to act in performing my tasks }\end{array}$ & 3.73 & 0.946 & 10.026 & 0.000 & High & 2 \\
\hline $11-$ & $\begin{array}{l}\text { My direct boss follow-up my performance and } \\
\text { provides his advice and the support in the } \\
\text { delegated tasks continuously }\end{array}$ & 3.62 & 0.843 & 0.921 & 0.358 & Medium & 3 \\
\hline $13-$ & $\begin{array}{l}\text { There are clear standards in the company for } \\
\text { delegating the authority }\end{array}$ & 3.44 & 0.946 & 9.717 & 0.000 & Medium & 9 \\
\hline $12-$ & $\begin{array}{l}\text { The company's management in which I work } \\
\text { provide me with the opportunity to make } \\
\text { decisions in my specialty independently }\end{array}$ & 3.39 & 0.896 & 5.632 & 0.000 & Medium & 5 \\
\hline $10-$ & $\begin{array}{l}\text { My bosses do not practice the authorities } \\
\text { delegated to me during the delegation period }\end{array}$ & 3.08 & 1.079 & 6.063 & 0.000 & Low \\
\hline $\begin{array}{l}\text { General mean and standard deviation for the } \\
\text { dimension delegating the authority }\end{array}$ & 3.50 & 070 & 6 \\
\hline
\end{tabular}

Table 3 shows description of these who occupy the supervisory jobs on the items related to the dimension delegating the authority.

Since the means ranged between $(3.08-3.63)$, and the highest mean was for the item (8), which its means (3.73) with standard deviation (0.880) and the lowest mean was for item (10), with mean (3.08) and standard deviation (1.079), and the general mean for the dimension reached (3.50) which indicates at a medium level of the dimension delegating the authority. 
Table 4.Means and Standard Deviation for the Dimension(giving the Required information)

\begin{tabular}{|c|c|c|c|c|c|c|c|}
\hline No. & The Item & Means & S.D & $\begin{array}{c}\mathrm{T} \\
\text { value }\end{array}$ & $\begin{array}{l}\text { Sig } \\
\text { level }\end{array}$ & $\begin{array}{l}\text { The } \\
\text { Level }\end{array}$ & $\begin{array}{l}\text { The } \\
\text { Rank }\end{array}$ \\
\hline $14-$ & $\begin{array}{l}\text { The company's management provides modern } \\
\text { devices and technologies to make available } \\
\text { information to the decision markers }\end{array}$ & 3.84 & 0.838 & 13.048 & 13.048 & High & 1 \\
\hline $10-$ & $\begin{array}{l}\text { The company management has special } \\
\text { technological facilities for distribution the } \\
\text { information specific to the work to the } \\
\text { employees like the e-mail. }\end{array}$ & 3.76 & 0.962 & 10.831 & 10.831 & High & 2 \\
\hline $15-$ & $\begin{array}{l}\text { The company's management makes available } \\
\text { the technical and the administrative required } \\
\text { sides to receive and exchange information. }\end{array}$ & 3.74 & 0.896 & 10.339 & 10.339 & High & 3 \\
\hline $17-$ & $\begin{array}{l}\text { The company's management determines the } \\
\text { cognitive needs to provide them and best } \\
\text { conditions to the attendants }\end{array}$ & 3.64 & 0.817 & 10.200 & 10.200 & Medium & 4 \\
\hline $19-$ & $\begin{array}{l}\text { The company codes the specific information to } \\
\text { work in anto refer to them when it is necessary. }\end{array}$ & 3.56 & 0.841 & 5.026 & 5.026 & Medium & 5 \\
\hline 18 & $\begin{array}{l}\text { The company builds organizational memory to } \\
\text { the experiences and experiments it passes } \\
\text { through and keeping them in data bases as } \\
\text { expert systems to refer to when needed. }\end{array}$ & 3.38 & 0.989 & 8.639 & 8.639 & Medium & 6 \\
\hline & $\begin{array}{l}\text { Mean and standard deviation for the dimension } \\
\text { giving the required information. }\end{array}$ & & & & & & \\
\hline
\end{tabular}

Table 4 shows description of these who occupy the supervisory and managerialjobs on the items related to the dimension giving the reluird information, since the means ranged on this variable between (3.38-3.84), and the highest mean was for item (14) with mean (3.84) and standard deviation (0.838), and the lowest mean was for item (18) with mean (3.38) and standard deviation (0.989), and the general mean for the dimension reached (3.65) on likert five points scales.

Table 5.Means and Standard Deviation for the Dimension (Participation)

\begin{tabular}{|c|l|c|c|c|c|c|c|}
\hline No. & \multicolumn{1}{|c|}{ The Item } & Means & S.D & $\begin{array}{c}\text { T } \\
\text { value }\end{array}$ & $\begin{array}{c}\text { Sig } \\
\text { level }\end{array}$ & $\begin{array}{c}\text { The } \\
\text { Level }\end{array}$ & $\begin{array}{c}\text { The } \\
\text { Rank }\end{array}$ \\
\hline 25 & $\begin{array}{l}\text { The company provides communication channels } \\
\text { specific to the public service and to communicate } \\
\text { with them }\end{array}$ & 3.50 & 0.929 & 3.240 & 0.01 & Medium & 1 \\
\hline 22 & $\begin{array}{l}\text { The company encourages knowledge transfer and } \\
\text { information between the divisions }\end{array}$ & 3.47 & 0.883 & 2.799 & 0.06 & Medium & 2 \\
\hline 23 & $\begin{array}{l}\text { The company interests in finding effective and } \\
\text { developed communication means between the } \\
\text { workers from different divisions and }\end{array}$ & 3.43 & 0.927 & 6.928 & 0.000 & Medium & 3 \\
\hline
\end{tabular}




\section{Macrothink}

Business and Economic Research

ISSN 2162-4860

2019, Vol. 9, No. 3

\begin{tabular}{|c|l|c|c|c|c|c|c|}
\hline & occupational titles & & & & & & \\
\hline 24 & $\begin{array}{l}\text { The company encourages communication } \\
\text { channels between top and middle management in } \\
\text { the frame of the work and out of it }\end{array}$ & 5.33 & 0.957 & 6.107 & 0.000 & Medium & 4 \\
\hline 26 & $\begin{array}{l}\text { The company allows the employees to participate } \\
\text { in the administrative decisions making affecting } \\
\text { the employees work }\end{array} 1$ & 3.24 & 0.968 & 4.475 & 0.000 & Medium & 5 \\
\hline $\begin{array}{l}\text { The company cares about finding effective means } \\
\text { for communication between the employees from } \\
\text { different division and job titles. }\end{array}$ & 3.21 & 9.83 & 7.078 & 0.000 & Medium & 6 \\
\hline $\begin{array}{l}\text { The general mean and standard deviation for the } \\
\text { dimension participation }\end{array}$ & 3.36 & 0.79 & & & \\
\hline
\end{tabular}

Table 5 clarifies the responses of those who occupy the supervisory and administrative jobs on the items related to the dimension participation, the mean ranged between (3.21-3.50), the highest mean was for item (25) with mean (3.50) and standard deviation (0.929) and the lowest item was number (23) with mean (3.21) and standard deviation (0.983), and the general mean for the dimension reached (3.36), indicate at medium level of the participation dimension.

Table 6.Means and Standard Deviation for the Dimension the Organizational Performance

\begin{tabular}{|c|l|l|l|l|l|l|c|}
\hline No. & \multicolumn{1}{|c|}{ The Item } & Means & S.D & $\begin{array}{c}\text { T } \\
\text { value }\end{array}$ & $\begin{array}{c}\text { Sig } \\
\text { level }\end{array}$ & $\begin{array}{c}\text { The } \\
\text { Level }\end{array}$ & $\begin{array}{c}\text { The } \\
\text { Rank }\end{array}$ \\
\hline 26 & $\begin{array}{l}\text { The company plans for the continuous } \\
\text { improvement in all fields. }\end{array}$ & 3.91 & 0.788 & 15.130 & 0.000 & High & 1 \\
\hline 30 & $\begin{array}{l}\text { The company works to achieve customers } \\
\text { satisfaction and loyalty which consider one of } \\
\text { the basics for the delivered services by the } \\
\text { company }\end{array}$ & 3.84 & 0.893 & 10.328 & 0.000 & High & 2 \\
\hline 35 & $\begin{array}{l}\text { The company cares about organizing services } \\
\text { characterize by quality to care about its } \\
\text { customers }\end{array}$ & 3.81 & 0.910 & 9.555 & 0.000 & High & 3 \\
\hline 32 & $\begin{array}{l}\text { The company study's needs and desires of the } \\
\text { customers and level of their satisfaction in a } \\
\text { periodic form. }\end{array}$ & 3.80 & 0.924 & 8.531 & 0.000 & High & 4 \\
\hline 31 & $\begin{array}{l}\text { The company works on improving and } \\
\text { organizing the provided services to the } \\
\text { customers continuously. }\end{array}$ & 3.79 & 0.889 & 12.253 & 0.000 & High & 5 \\
\hline 36 & $\begin{array}{l}\text { The company markets its services through the } \\
\text { technology to guarantee the customers loyalty. }\end{array}$ & 3.75 & 0.963 & 11.610 & 0.000 & High & 6 \\
\hline 27 & $\begin{array}{l}\text { The company regularly provides times, the staff, } \\
\text { the facilities, equipments and the sufficient } \\
\text { funds to implement activities related to }\end{array}$ & 3.73 & 0.926 & 11.335 & 0.000 & High & 7 \\
\hline
\end{tabular}




\begin{tabular}{|c|c|c|c|c|c|c|c|}
\hline & customers service. & & & & & & \\
\hline 28 & $\begin{array}{l}\text { The company periodically follow up the } \\
\text { customers complaints and provides the solution } \\
\text { for them if possible. }\end{array}$ & 3.70 & 0.952 & 7.623 & 0.000 & High & 8 \\
\hline 29 & $\begin{array}{l}\text { There is an effective communication system } \\
\text { between top management and the public }\end{array}$ & 3.59 & 0.905 & 8.132 & 0.000 & Medium & 9 \\
\hline 34 & $\begin{array}{l}\text { The company satisfies the urgent needs and the } \\
\text { new needs through the organization and the } \\
\text { procedures and service delivery means. }\end{array}$ & 3.59 & 0.950 & 11.603 & 0.000 & Medium & 10 \\
\hline 33 & $\begin{array}{l}\text { The company designs its organizational } \\
\text { processes in away corresponds with the } \\
\text { customers satisfaction and suggestions. }\end{array}$ & 3.58 & 0.993 & 10.243 & 0.000 & Medium & 11 \\
\hline & $\begin{array}{l}\text { General mean and standard deviation for the } \\
\text { dimension the organizational performance }\end{array}$ & 3.74 & 0.75 & & & & \\
\hline
\end{tabular}

Table 6 clarifies description of those who occupy the supervisory jobs on the items related to the dimension the organizational performance, since the means ranged for this dimension between (3.58-3.91), and the highest mean was for item (25), which its means was (3.91), and with standard deviation (0.788), and the lowest mean was for item (33) with mean (3.58) with standard deviation (0.993), and the general mean for the dimension reached (3.74) with standard deviation $(0.75)$.

\section{Testing the Research Hypothesis}

\subsection{Research Hypothesis}

Ho1: There is no linear relationship between empowerment variables and employees reality and reducing turnover variables at significance level $(\mathrm{a} \leq 0.05)$.

Ho2: There is no effect with statistically significance of the empowerment variables in employees' reality and turnover variables.

Ho3: There is no effect of the empowerment variables in employees reality and reducing turnover (customers service and customers loyalty).

\subsection{First Hypothesis}

Ho1: There is no linear relationship, giving the empowerment variables (Training, giving the required information, delegating the authority, and the participation) with the employees reality and reducing turnover (customers service and customer loyalty) at significance level $(\mathrm{a} \leq 0.05)$.

To test this hypothesis, the Canonical, correlation Analysis has been used.

Table 7.Results of the Canonical analysis between the empowerment variables and employees reality and turnover variables

\begin{tabular}{|c|c|c|c|c|c|}
\hline \multirow[t]{2}{*}{ The variables } & \multirow[t]{2}{*}{ Canonical Rates } & \multicolumn{2}{|c|}{ Structured Weight } & \multirow{2}{*}{$\begin{array}{l}\text { Correlation } \\
\text { Coefficient }\end{array}$} & \multirow{2}{*}{$\begin{array}{c}\mathrm{R}^{2} \\
\text { Canonical }\end{array}$} \\
\hline & & Customers & Customers & & \\
\hline
\end{tabular}




\section{Macrothink}

Business and Economic Research

ISSN 2162-4860

2019, Vol. 9, No. 3

\begin{tabular}{|c|c|c|c|c|c|}
\hline & & loyalty & service & & Coefficient \\
\hline \multirow{4}{*}{$\begin{array}{c}\text { Managerial } \\
\text { Empowerment }\end{array}$} & Training dimension & \multicolumn{2}{|c|}{0.49} & 0.49 & 0.49 \\
\hline & $\begin{array}{c}\text { Delegating the } \\
\text { authority dimension }\end{array}$ & \multicolumn{2}{|c|}{0.49} & 0.48 & 0.51 \\
\hline & $\begin{array}{l}\text { Giving the required } \\
\text { information }\end{array}$ & \multicolumn{2}{|c|}{0.60} & 0.63 & 0.57 \\
\hline & $\begin{array}{l}\text { Participation } \\
\text { dimension }\end{array}$ & \multicolumn{2}{|c|}{0.67} & 0.68 & 0.65 \\
\hline \multirow{2}{*}{$\begin{array}{l}\text { Employees reality } \\
\text { and reduction }\end{array}$} & Customers service & & & 0.74 & 0.597 \\
\hline & Customers loyalty & & & & \\
\hline
\end{tabular}

Table 7 clarifies this relationship between empowerment variables and employees reality and reducing turnover, the results showed the presence of a relation between the empowerment variables and employees reality and turnover reduction, the canonical correlations ratios between empowerment dimensions with employees reality and turnover reduction reached $(0.49,0.49,0.60$, and 0.67$)$ since participation has the highest $\mathrm{R}^{2}$ and the organizational performance $\mathrm{R}^{2}$ on empowerment reached $(0.57,0.56)$, this indicates at the close $\mathrm{R}^{2}$ for employees reality, and turnover reduction.

The canonical correlation coefficient between the research's independent variables and the dependent variables reached (0.74).

It is possible to infer fro the results the presence of a linear canonical relationship between the empowerment variables and employees reality and turnover reduction at $(\mathrm{a} \leq 0.05)$.

\subsection{Second Hypothesis}

For Ho2: Results showed the presence of effect with statistical significance of the administrative empowerment variables in the variables employees reality and turnover reduction.

\subsection{Third Hypothesis}

Regarding Ho3: Results of the stepwise multiple regression correlation coefficient showed that the coefficient for the research's independent variables collectively reached (54\%), while the contributions of the administrative empowerment variables individually for the variables (participation, training and giving the required information) were $(1 \% \mathrm{~m}, 6 \%, 87 \%) \mathrm{m}$, and all (E) statistical values were significant at sig. level $(a \leq 0.05)$, while delegating the authority its values did not reach influence sig. level which means there is an effect with statistical significance between the administrative empowerment variables in the organizational performance.

This result indicates that the participation dimension as one of the empowerment dimensions its influence value individually was (0.06) on the organizational performance, and (0.47) in the employees reality and turnover reduction. 


\section{1) Macrothink}

Business and Economic Research

ISSN 2162-4860

2019, Vol. 9, No. 3

\section{Research's Results}

1. Mean of practicing empowerment with its dimensions reached medium degree3.

2. Employees reality and turnover reduction dimensions reached high degree of practice.

3. The presence of a canonical correlation between empowerment variables and employees reality and turnover reduction at significance level $(\mathrm{a} \leq 0.05)$.

4. Result of this study agree with Falaq and Gen Nafleh study (2011),1 which showed effect with statistical significance of the empowerment fields in the administrative creativity, and disagree with Al-Rasheedi study (2001) whjich showed the absence of differences with statistical significance between means of the study sample individuals toward the psychological empowerment attribute to the demographic variables; and agree with Glor (2001) study which reached that employees empowerment enhanced as a strategic approach at high degree.

\section{Recommendations}

Based on the results, the study recommending the follow:

1. The work for disseminating the managerial empowerment culture between employees in the companies through enhancing the organizational values and traditions motivating for that goal.

2. The interest in developing and training the employees according to scientific programs aim at developing their capabilities and improving level of their performance.

3. Conducting short and medium term training programs to train the employees.

4. Encouraging and supporting the employees continuously in the education in all fields relating to their work.

5. Providing the opportunities to apply the acquired skills from training.

6. Expansion in delegating the authorities to the employees and engaging them in making the decisions and the policies relating to their work through work teams or committees to raise their moral spirit and to support the trust and cooperation climate between them to contribute to empowerment success.

\section{References}

Al-as, S., \& Ali, A. (2013).Human Resources Management.Dar Wa'el for Publication and Distribution, Amman, Jordan.

Al-Awad, F., \& Al-harran, M. (2009).Factors Affecting the organizational commitment of the teaching staff members King Saud University Al-Riyadh: Research Center, Faculty of the Managerial Sciences.King Saud University, No. (1), 15-65.

Al-obaidi, J. (2012) Effect of the Creative Orientation and Training Strategy in the Employees Performance in the Kuwait oil company.Unpublished Master Thesis Middle East University, Amman, Jordan. 
Al-otaibi, S. (2000). Employees Empowerment: As a strategy for the Managerial Development: The Twelfth Regional Meeting for the web and Human Resources Development, Masqat, Oman, 11-13.

Alrasheedi, S. (2011).Effect of the Psychological Empowerment in Achieving the Competitive Advantage" Field study on the Kuwaiti insurance companies. unpublished Master Thesis, Al-Albait University. Al-Mafraq, Jordan.

Alsamerrai, A. (2010). Effect of the Training Strategies in Developing the Human Resources in the Pubic Sector, the Electricity sector As a model. Master Thesis in the Managerial Sciences, the Arabic Academy in Denmark.

Batayneh, L. (2003). Effect of Empowerment and the organizational support in the Employees Excellent Behavior in the Jordanian pubic sector: A Field study from the point of view of Directors of the Public Directorates in the North District.Master Thesis, Yarmouk University, Irbid, Jordan.

Falaq, M., \& Ben, N. Q. (2011). Effect of the managerial Empowerment in the Employees Creativity: A Case Study of the Jordanian communications Group (Orange) Journal Al-basa'er. Arbitrated Scientific Journal, 12(1).

Ham'ood, Kh., \& Al-Loozi, M. (2008). Principles of Business Administration.Ithra for Publication and Distribution, Jordan.

Ham'ood, Kh., \& Al-Loozi, M. (2008). Principles of Business Administration.Ithra for Publication and Distribution, Jordan.

Lee, H. (2012). An Empirical study of organizational justice as a mediator of the relationships among leader member exchange and job satisfaction.Organizational commitment and turnover intention in the lodging industry.Unpublished PhD Dissertation, Virginia State University, USA.

Moke, E. (2012). Relationships Between Organizational Climate and Empowerment of Nurses in Hong Kong. Nurses Review, 10(3), 1-19.

https://doi.org/10.1046/j.1365-2834.2002.00285.x

Morgan, N., \& Mason, Ch. (2009).Market Orientation, Marketing Capabilities and Firm Performance.Strategic Management Journal, 30, 909-920. https://doi.org/10.1002/smj.764

Oyden, S., \&Margisonm, D. (2012). Empowerment and Accountability: Evidence From the UK Privatized Water Industry.Journal of Management Studies, 43(3), 521-555.

https://doi.org/10.1111/j.1467-6486.2006.00600.x

Sarina, I. (2009). The Effect of Customers' Satisfaction Towards Customer Loyalty Among mobile Telecommunication providers in Malaysia. unpublished MSC, Utara University, Malaysia.

Stirr, Th. (2003).Breaking out The Big idea. Marketing Magazine, Website.

Wheelen, Th., \& Hunger, D. (2009). Strategic Management and Business Policy: Prentice 
Hall. Upper Saddle River $\mathrm{Nj}$.

\section{Copyright Disclaimer}

Copyright for this article is retained by the author(s), with first publication rights granted to the journal.

This is an open-access article distributed under the terms and conditions of the Creative Commons Attribution license (http://creativecommons.org/licenses/by/3.0/).s 